\title{
MENINGKATKAN KEMAMPUAN MEMBACA PEMAHAMAN SISWA MELALUI METODE MEMBACA KRITIS PADA SISWA KELAS V SD NEGERI 18 KAMPUNG PANSUR KECAMATAN KOTO XI TARUSAN TAHUN PELAJARAN 2014/2015
}

\section{Yarfriaty}

\section{Abstrak}

Proses pembelajaran merupakan suatu kegiatan kurikulum dalam lembaga pendidikan sebagai upaya mempengaruhi para peserta didik untuk mencapai tujuan pendidikan yang telah ditetapkan. Tujuan pendidikan itu sendiri pada dasarnya mengantarkan para peserta didik menuju pada perubahanperubahan tingkah laku baik intelektual, moral, maupun sosial agar dapat hidup mandiri sebagai individu dan makhluk sosial. Akan tetapi berbicara masalah pendidikan, kadangkala dihadapkan pada mata rantai persoalan yang tidak jelas ujung pangkalnya dan dari mana harus memulainya.

Penelitian ini Tujuan penelitian yang dicapai pada hakikatnya adalah menjawab pertanyaan yang dikemukakan pada rumusan masalah, adapun tujuan dari penelitian ini yaitu: Untuk meningkatkan kemampuan siswa dalam membaca pemahaman melalui metode membaca kritis.

Jenis penelitian ini adalah penelitian tindakan kelas (classroom action research) yang akan dilaksanakan dalam dua siklus. Jenis penelitian tindakan kelas ini dipilih dengan tujuan agar mampu menawarkan cara baru untuk memperbaiki dan meningkatkan profesionalisme guru dalam kegiatan belajar mengajar dikelas dengan melihat berbagai indikator keberhasilan proses dan hasil belajar". Selain itu penelitian tindakan kelas ini di anggap mudah karena hanya melalui empat tahapan yaitu perencanaan, aksi, observasi dan refleksi.

Hasil penelitian ini menunjukkan Menumbuhkan atau meningkatkan minat membaca dalam keterampilan berbahasa Indonesia dapat memberikan pengaruh yang positif sehingga siswa merasakan pada dirinya ada perubahan berupa kemajuan dalam belajarnya karena dirinya telah termotivasi sehingga minat membaca meningkat dan bergairah untuk belajar.

Guru memberikan kebebasan kepada siswa untuk menanyakan secara individual tentang apa saja yang belum dipahaminya. Pertanyaan siswa secara individual dijawab oleh guru juga secara indidual. Guru juga memberikan kesempatan kepada siswa untuk berlomba mendapatkan nilai yang terbaik. Beberapa hal yang dicatat pada pertemuan siklus I ini antara lain : Waktu yang dipergunakan mengerjakan pertanyaan belum merata, Kurang telitinya siswa dalam menulis jawaban pertanyaan yang tersedia.

Keyword: Metode Membaca Kritis ; Bahasa Indonesia; SD.

Copyright (C) 2016 IICET (Padang - Indonesia) - All Rights Reserved

Indonesian Institute for Counseling, Education and Theraphy (IICET)

\section{PENDAHULUAN}

Proses pembelajaran merupakan suatu kegiatan kurikulum dalam lembaga pendidikan sebagai upaya mempengaruhi para peserta didik untuk mencapai tujuan pendidikan yang telah ditetapkan. Tujuan pendidikan itu sendiri pada dasarnya mengantarkan para peserta didik menuju pada perubahan-perubahan tingkah laku baik intelektual, moral, maupun sosial agar dapat hidup mandiri sebagai individu dan makhluk sosial. Akan tetapi berbicara masalah pendidikan, kadangkala dihadapkan pada mata rantai persoalan yang tidak jelas ujung pangkalnya dan dari mana harus memulainya. Betapa pentingnya pendidikan dalam kehidupan manusia, sehingga dengan demikian manusia dituntut untuk menuntut ilmu pengetahuan itu melalui proses pendidikan yang dimaksudkan di atas. Salah satu unsur yang paling penting dalam proses pendidikan adalah belajar.

Belajar merupakan suatu proses usaha yang dilakukan individu untuk memperoleh suatu perubahan tingkah laku yang baru sebagai hasil pengalaman individu itu sendiri dalam interaksi dengan lingkungannya. Bahasa Indonesia merupakan salah satu materi pembelajaran yang sangat penting di pelajari khususnya pada tingkat sekolah dasar. Sebab di sekolah dasar merupakan proses awal untuk pembentukan karakter siswa yang 
nantinya akan meningkat pada jenjang selanjutnya. Bahasa Indonesia sebagai alat komunikasi dan sarana yang sangat penting dalam kehidupan sehari-hari, selain sebagai alat untuk menyatakan pikiran dan perasaan terhadap orang lain serta berfungsi memahami pikiran dan perasaan orang lain. (Depdikbud 1996:3),menyatakan bahwa pengembangan Linguistik Intelegensi (kemampuan/ kecerdasan berbahasa) bertujuan agar manusia mampu berkomunikasi secara lisan dengan lingkungan teman sebaya dengan menggunakan bahasa Indonesia, baik di sekolah, di rumah, maupun di sekitar tempat tinggal.

Bahasa Indonesia, sebagai bahasa nasional telah diajarkan pada semua jenjang pendidikan mulai dari sekolah dasar sampai jenjang perguruan tinggi. Hal ini dimaksudkan agar murid atau siswa mampu dan terampil menggunakan kalimat bahasa Indonesia di kalangan masyarakat, namun sampai sekarang boleh dikatakan hasil yang dicapai dalam pengajaran bahasa Indonesia belum memuaskan. Hal ini dapat dilihat dari beberapa peneliti yang pernah dilakukan, sebelumnya oleh: Jusuf Arruan pada tahun 1991, Silvija M. Rokot tahun 1995, dan Cotaji M Kumenap pada tahun 1994. Dari penelitian tersebut masing-masing menyatakan bahwa pengajaran bahasa Indonesia belum memuaskan.

Mempelajari bahasa Indonesia merupakan hal yang sangat penting untuk dipelajari oleh setiap manusia khususnya siswa kelas V SD Negeri 18 Kampung Pansur Kecamatan Koto XI Tarusan Tahun Pelajaran 2014/2015. Akan tetapi pengetahuan Bahasa Indonesia tidak muda untuk ditransfer begitu saja tetapi butuh proses pembelajaran. Keterampilan dalam kemampuan berbahasa meliputi empat aspek, yaitu menyimak, berbicara, membaca, dan menulis yang berdasarkan pada kurikulum 1994 maupun dalam kurikulum 2004 yang berbasis kompetensi. Keempat aspek keterampilan ini menjadi faktor pendukung dalam menyampaikan pikiran, gagasan, dan pendapat, baik secara lisan maupun tertulis, sesuai dengan konteks komunikasi yang harus dikuasai oleh pemakai bahasa. Berdasarkan keempat aspek kemampuan berbahasa tersebut, tujuan umum pembelajaran berbahasa dapat tercapai (Depdiknas, 2003: 3).

Hal ini senada yang di ungkapkan oleh Lorbach dan Tobin (Efi, 2007 : 4) mengatakan bahwa pengetahuan tidak dapat ditransfer begitu saja dari otak seorang guru kepada siswa, siswa yang harus memaknai apa yang telah di ajarkan dengan menyesuaikan terhadap pemahamannya. Proses belajar yang dimaksud disini adalah sebuah proses yang di lakukan dengan penerapan beberapa metode dan kemampuan tenaga pendidik untuk memberikan stimulus kepada siswa sehingga siswa dengan kemampuannya yang di bekali dengan ilmu pengetahuan mampu memahami pelajaran yang diberikan oleh guru. Hasil yang dicapai siswa kelas V SD Negeri 18 Kampung Pansur Kecamatan Koto XI Tarusan Tahun Pelajaran 2014/2015 sebelum dilakukan penelitian menunjukkan nilai di bawah standar minimal (55\%). Dan untuk mengetahui secara pasti manfaat dari penerapan metode membaca kritis pada siswa perlu dilakukan penelitian secara mendalam. Dalam penelitian ini, siswa di harapkan mampu mencapai keriteria ketuntasan minimal (65-85\%), dan mampu memberikan umpan balik dalam artian memberikan respon terhadap proses membaca materi yang disajikannya. Dan untuk memiliki kemampuan pemahaman kritis terhadap materi bacaan maka, diperlukan latihan yang sistematis dan terarah yang tentunya di dahului oleh pola yang diterapkan oleh tenaga pendidik. Dalam proses belajar-mengajar, salah satu pendekatan yang ingin diterapkan adalah kemampuan membaca pemahaman dengan metode membaca kritis.

\section{METODELOGI PENELITIAN}

Jenis penelitian ini adalah penelitian tindakan kelas (classroom action research ) yang akan dilaksanakan dalam dua siklus. Jenis penelitian tindakan kelas ini dipilih dengan tujuan agar mampu menawarkan cara baru untuk memperbaiki dan meningkatkan profesionalisme guru dalam kegiatan belajar mengajar dikelas dengan melihat berbagai indikator keberhasilan proses dan hasil belajar". Selain itu penelitian tindakan kelas ini di anggap mudah karena hanya melalui empat tahapan yaitu perencanaan, aksi, observasi dan refleksi.

Adapun waktu dan tempat penelitian yaitu bertempat di SD Negeri 18 Kampung Pansur Kecamatan Koto XI Tarusan Tahun Pelajaran 2014/2015. Penelitian ini direncanakan dilaksanakan selama 2 bulan yaitu bulan September sampai dengan bulan Oktober 2014.

Penelitian ini dilakukan di SD Negeri 18 Kampung Pansur Kecamatan Koto XI Tarusan Tahun Pelajaran 2014/2015. Sebagai subjek penelitian adalah siswa SD Negeri 18 Kampung Pansur Kecamatan Koto XI Tarusan Tahun Pelajaran 2014/2015 khususnya Kelas V dengan jumlah siswa 37 orang yang terdiri atas 14 laki-laki dan 23 perempuan. 
Adapun fokus perhatian dalam penelitian ini adalah meningkatkan hasil belajar melalui penerapan metode membaca kritis. Disamping itu juga akan dilihat minat dan motivasi siswa dalam membaca pada mata pelajaran Bahasa Indonesia di Sekolah dasar (SD).

Data yang terkumpul berupa data kuantitatif dianalisis dengan perhitungan persentase. Teknik ini digunakan untuk memperoleh gambaran umum mengenai perilaku siswa dalam proses pembelajaran, efektivitas tindakan, dan hambatan-hambatan yang dihadapi dalam pelaksanaan penelitian tindakan kelas serta hasil belajar yang dicapai siswa di setiap akhir siklus. Indikator keberhasilan penelitian tindakan kelas adalah bila hasil belajar murid selama proses penbelajaran tiap siklus mengalami peningkatan dari siklus I ke siklus II. Hal ini di tandai dengan daya serap individu minimal 65\% dan ketuntasan klasikal $85 \%$ serta observasi murid dan pengelolaan pembelajaran berada dalam kategori sangat baik.

\section{HASIL DAN PEMBAHASAN PENELITIAN \\ Hasil Penelitian Siklus I}

Menumbuhkan atau meningkatkan minat membaca dalam keterampilan berbahasa Indonesia dapat memberikan pengaruh yang positif sehingga siswa merasakan pada dirinya ada perubahan berupa kemajuan dalam belajarnya karena dirinya telah termotivasi sehingga minat membaca meningkat dan bergairah untuk belajar. Guru memberikan kebebasan kepada siswa untuk menanyakan secara individual tentang apa saja yang belum dipahaminya. Pertanyaan siswa secara individual dijawab oleh guru juga secara indidual. Guru juga memberikan kesempatan kepada siswa untuk berlomba mendapatkan nilai yang terbaik. Beberapa hal yang dicatat pada pertemuan siklus I ini antara lain adalah waktu yang dipergunakan mengerjakan pertanyaan belum merata dan Kurkng telitinya siswa dalam menulis jawaban pertanyaan yang tersedia.

Berikut ini data siswa yang menunjukkan meningkatnya minat siswa pada siklus I pada saat mengerjakan LKS.

Tabel 1

Minat Siswa Pada Saat Pengerjaan LKS Siklus I

\begin{tabular}{|c|l|c|c|}
\hline NO & \multicolumn{1}{|c|}{ Indikator } & Jumlah Siswa & Prosentase \% \\
\hline 1. & Tidak suka membuang waktu & 8 & 62 \\
\hline 2 & Aktivitas yang sangat tinggi & 8 & 69 \\
\hline 3 & Mengerjakan tepat waktu & 8 & 62 \\
\hline 4 & Mengerjakan sebaik mungkin & 8 & 62 \\
\hline 5 & Bergairah belajar & 8 & 62 \\
\hline \multicolumn{2}{r|}{ Rata-rata } & 8.2 & 63.4 \\
\hline
\end{tabular}

Dari data di atas dapat disimpulkan bahwa pada siklus ini minat membaca siswa belum memenuhi harapan(masih dibawah 75\%). Pada tahap selanjutnya guru mengajak siswa untuk membahas hasil pengerjaan LKS dengan cara member kebebasan siswa menulis jawaban di papan tulis. Selanjutnya pembahasan tentang jawaban yang telah ditulis di papan tulis. Siswa yang jawabannya salah atau kurang sempurna harus menyempunakan jawabannya. Hal ini dimaksudkan agar pada kegiatan selanjutnya tidak mengalami kesalahan. Apabila tidak diperbaiki, kesalahan ini terbawa pada kegiatan-kegiatan selanjutnya.

Berikut daftar aktivitas yang menunjukkan menngkatnya minat berprestasi siswa pada siklus pertama pada saat pembahasan LKS.

Tabel 2.

Minat Siswa pada pembahasan LKS Siklus I

\begin{tabular}{|c|l|c|c|}
\hline NO & \multicolumn{1}{|c|}{ Indikator } & Jumlah Siswa & Prosentase \% \\
\hline 1. & Tidak suka membuang waktu & 10 & 76 \\
\hline 2 & Aktivitas yang sangat tinggi & 10 & 76 \\
\hline 3 & Mengerjakan tepat waktu & 9 & 69 \\
\hline 4 & Mengerjakan sebaik mungkin & 9 & 69 \\
\hline 5 & Bergairah belajar & 11 & 85 \\
\hline \multicolumn{2}{r}{ Rata-rata } & 9.8 & 75 \\
\hline
\end{tabular}

Dari data di atas dapat disimpulkan bahwa pada siklus I pembahasan LKS minat siswa sudah cukup baik, rata-rata mencapai $75 \%$.

Pada akhir tahap ini guru memberikan penelitian akan hasil tugas siswa. Hal ini dimaksudkan untuk memberikan motivasi siswa bahwa semakin sempurna dan teliti jawabannya akan mendapat nilai yang lebih baik. Kemudian diadakan ulangan tertulis yang bahannya dari semua bahan yang dipelajari siswa sebanyak 
sepuluh soal dengan waktu sepuluh menit. Pada saat mengerjakan evaluasi terlihat adanya minat dan motivasi siswa untuk lebih berprestasi mengerjakan sebaik-baiknya. kelompok.

Berikut data aktivitas siswa yang menunjukkan minat belajar siswa pada siklus I pada saat diskusi

Tabel. 3.

Minat siswa pada Saat Diskusi Siklus I

\begin{tabular}{|c|l|c|c|}
\hline NO & \multicolumn{1}{|c|}{ Indikator } & Jumlah Siswa & Prosentase \% \\
\hline 1. & Tidak suka membuang waktu & 10 & 76 \\
\hline 2 & Aktivitas yang sangat tinggi & 10 & 76 \\
\hline 3 & Mengerjakan tepat waktu & 10 & 76 \\
\hline 4 & Mengerjakan sebaik mungkin & 10 & 76 \\
\hline 5 & Bergairah belajar & 11 & 85 \\
\hline \multicolumn{2}{r|}{ Rata-rata } & 10.2 & 77.8 \\
\hline
\end{tabular}

Dari data diatas dapat disimpulkan bahwa minat dalam mengikuti diskusi Tanya jawab sudah cukup baik yaitu mencapai nilai rata-rata $77.8 \%$. Pada saat pengerjaan evaluasi terlihat adanya minta untuk berpartisipasi dengan mengerjakan sebaik-baiknya.

Tabel 4.

Minat Siswa Pada Saat Evaluasi Siklus I

\begin{tabular}{|c|l|c|c|}
\hline NO & \multicolumn{1}{|c|}{ Indikator } & Jumlah Siswa & Prosentase \% \\
\hline 1. & Tidak suka membuang waktu & 11 & 85 \\
\hline 2 & Aktivitas yang sangat tinggi & 10 & 76 \\
\hline 3 & Mengerjakan tepat waktu & 10 & 76 \\
\hline 4 & Mengerjakan sebaik mungkin & 10 & 76 \\
\hline 5 & Bergairah belajar & 11 & 85 \\
\hline \multicolumn{2}{|c|}{ Rata-rata } & 10.4 & 79.6 \\
\hline
\end{tabular}

Dari data diatas tersebut menunjukkan bahwa motivasi (minat) siswa dalam evaluasi ini cukup baik, mencapai rata-rata $79.6 \%$.

Pada akhir kegiatan guru dan siswa memberikan beberapa kesimpulan kegiatan dan memberikan penilaian terhadap aktivitas siswa selama kegiatan dan memberikan penyempurnaan kegiatan selanjutnya.

\section{Hasil Belajar}

Berdasarkan ulanga harian yang telah dilaksanakan menunjukkan bahwa telah ada peningkatan hasil belajar daripada pertemuan sebelum dilaksanakan penelitian walaupun kenaikan belum signifikan. Beberapa siswa telah menunjukkan hasil yang nilainya rendah kurang dari 6,00.

Tabel 4.5.

Hasil Evaluasi Belajar Siklus I

\begin{tabular}{|l|c|c|c|c|c|c|}
\hline \multicolumn{1}{|c|}{ Nama } & MIN & BC & MB & JML & $\begin{array}{c}\text { Rata- } \\
\text { rata }\end{array}$ & \% \\
\hline Cevin Abiel Adha & 60 & 60 & 60 & 180 & 60 & 60 \\
\hline Santia Ersan & 60 & 70 & 60 & 190 & 63 & 63 \\
\hline Valino Aditama M.P & 90 & 90 & 90 & 270 & 90 & 90 \\
\hline Edwar Ridho & 80 & 85 & 85 & 250 & 83 & 83 \\
\hline
\end{tabular}




\begin{tabular}{|l|c|c|c|c|c|c|}
\hline Wini Oktaviani & 95 & 95 & 95 & 285 & 95 & 95 \\
\hline Saptia Melisa & 95 & 95 & 95 & 285 & 95 & 95 \\
\hline Revan Putra & 65 & 70 & 80 & 217 & 72 & 72 \\
\hline Febri Oktapian & 80 & 85 & 90 & 255 & 85 & 85 \\
\hline Khorida Adilla & 80 & 80 & 85 & 245 & 82 & 82 \\
\hline Aditia Pareza & 95 & 95 & 95 & 285 & 95 & 95 \\
\hline Muharriyatullah & 95 & 95 & 95 & 285 & 95 & 95 \\
\hline Abil Latura & 60 & 70 & 80 & 210 & 70 & 70 \\
\hline Dini Hidayatullah & 60 & 70 & 60 & 190 & 63 & 63 \\
\hline Junasril & 60 & 60 & 60 & 180 & 60 & 60 \\
\hline & 1075 & 1120 & 1130 & 3325 & 1108 & 1108 \\
\hline
\end{tabular}

Dari hasil evaluasi belajar tersebut nilai rata-rata 78.1 maka dapat disimpilkan bahwa menumbuhkan minat membaca dapat meningkatkan keterampilan berbahasa Indonesia.

\section{Rekomendasi Siklus I}

Walau pada siklus I ini menunjukkan hasil yang baik tetapi beberapa catatan penyempurnaan masih perlu dilakukan sebagai berikut :

1) Tata tertib belajar perlu disempurnakan antara lain :

- Perlu adanya pelaksanaan pembatasan waktu pengerjaan LKS

- Ketelitian siswa dalam penulisan jawaban

- Kelengkapan jawaban

2) Pada saat Pembahasan LKS

- Guru sebaiknya menuliskan nomor soal yang akan diisi oleh siswa secara berurutan di papan tulis kemudian menunjukkan siswa untuk mengisi.

- Penukaran buku LKS untuk dilakukan pemeriksaan ulang.

3). Pada saat diskusi, tempat duduk siswa sebaiknya berdekatan dengan anggota kelompoknya untuk mempercepat berkumpulnya kelompok.

\section{Hasil Penelitian Siklus II}

Dengan melihat hasil rekomendasi pada siklus I, peneliti telah melakukan penyempurnaan pada siklus II. Pada saat pembukan pelajaran guru memberikan pengarahan ulang tentang tata cara belajar yang disempurnakan dari siklus I, meliputi :

Tabel 6.

Minat siswa Pada Pengerjaan LKS Siklus II

\begin{tabular}{|c|l|c|c|}
\hline NO & \multicolumn{1}{|c|}{ Indikator } & Jumlah Siswa & Prosentase \% \\
\hline 1. & Tidak suka membuang waktu & 8 & 85 \\
\hline 2 & Aktivitas yang sangat tinggi & 9 & 76 \\
\hline 3 & Mengerjakan tepat waktu & 7 & 76 \\
\hline 4 & Mengerjakan sebaik mungkin & 10 & 85 \\
\hline 5 & Bergairah belajar & 14 & 85 \\
\hline \multicolumn{2}{r|}{ Rata-rata } & 10,6 & 81,4 \\
\hline
\end{tabular}


Dari data di atas dapat dilihat bahwa siklus II ini terjadi peningkatan minat siswa pada saat mengerjakan LKS, yaitu sebesar $18 \%$ bila dibandingkan dengan siklus I.

Pada saat pembahasan LKS pada siklus II, guru tidak lagi memberikan kebebasan terhadap siswa untuk menjawab soal di papan tulis, tetapi guru membatasi dengan menuliskannomor-nomor yang akan dijawab untuk menunjukkan deret-deret siswa yang akan menjawab. Dengan cara ini pelajaran di papan tulis lebih terorganisasi. Disamping itu guru membatasi jumlah siswa yang akan mengerjakan di papan tulis. Dengan cara ini dapat diperoleh efisiensi waktu dan ketentuan pengerjaan di papan tulis dan pembahasan cepat dilaksanakan.

Berikut data aktivitas siswa menunjukkan minat berprestasi siswa pada siklus II, pada saat pembahasan LKS di papan Tulis.

Tabel 7.

Minat Berprestasi Pada Pembahasan LKS Siklus II

\begin{tabular}{|c|l|c|c|}
\hline NO & \multicolumn{1}{|c|}{ Indikator } & Jumlah Siswa & Prosentase \% \\
\hline 1. & Tidak suka membuang waktu & 6 & 85 \\
\hline 2 & Aktivitas yang sangat tinggi & 8 & 85 \\
\hline 3 & Mengerjakan tepat waktu & 10 & 76 \\
\hline 4 & Mengerjakan sebaik mungkin & 9 & 85 \\
\hline 5 & Bergairah belajar & 15 & 85 \\
\hline \multicolumn{2}{r}{ Rata-rata } & 10.8 & 83.2 \\
\hline
\end{tabular}

Dari data di atas diperoleh minat belajar siswa mengalami peningkatan sebesar $8,2 \%$ bila dibandingkan Siklus I. Siklus II ini diberi waktu 10 menit untuk diskusi kelompok, semangat siswa dalam melakukan diskusi cukup tinggi. Berikut data aktivitas siswa yang menunjukkan minat belajar siswa pada siklus II pada saat siswa berdiskusi.

Tabel 8.

Minat Berprestasi Berdiskusi Siklus II

\begin{tabular}{|c|l|c|c|}
\hline NO & \multicolumn{1}{|c|}{ Indikator } & Jumlah Siswa & Prosentase \% \\
\hline 1. & Tidak suka membuang waktu & 12 & 85 \\
\hline 2 & Aktivitas yang sangat tinggi & 15 & 85 \\
\hline 3 & Mengerjakan tepat waktu & 10 & 85 \\
\hline 4 & Mengerjakan sebaik mungkin & 15 & 85 \\
\hline 5 & Bergairah belajar & 16 & 92 \\
\hline \multicolumn{2}{r}{ Rata-rata } & 11,2 & 86,4 \\
\hline
\end{tabular}

Dari data diatas dapat disimpulkan bahwa keikutsertaan siswa dalam melaksanakan diskusi mengalami peningkatan sebesar $8,6 \%$ bila dibandingkan dengan siklus I.

Tabel 9.

Minat Berprestasi Pada Evaluasi Siklus II

\begin{tabular}{|c|l|c|c|}
\hline NO & \multicolumn{1}{|c|}{ Indikator } & Jumlah Siswa & Prosentase \% \\
\hline 1. & Tidak suka membuang waktu & 8 & 92 \\
\hline 2 & Aktivitas yang sangat tinggi & 12 & 92 \\
\hline 3 & Mengerjakan tepat waktu & 11 & 85 \\
\hline 4 & Mengerjakan sebaik mungkin & 9 & 92 \\
\hline 5 & Bergairah belajar & 12 & 92 \\
\hline \multicolumn{2}{r|}{ Rata-rata } & 11,8 & 90,6 \\
\hline
\end{tabular}


Dari data diatas menunjukkan rata-rata berprestasi siswa mengalami peningkatan sebesar $11 \%$ dibandingkan siklus I.

Hasil yang diraih siswa pada siklus II ini mengalami peningkatan yang cukup signifikan. Keteraturan yang diciptakan oleh guru dalam pembelajaran ini membuahkan hasil positif berupa peningkatan hasilbelajar dari siklus I ke siklus II.

Tabel 10.

Hasil evaluasi Belajar Siklus II

\begin{tabular}{|c|c|c|c|c|c|c|}
\hline Nama & MIN & $\mathrm{BC}$ & MB & JML & $\begin{array}{c}\text { Rata- } \\
\text { rata }\end{array}$ & $\%$ \\
\hline Cevin Abiel Adha & 75 & 75 & 75 & 225 & 75 & 75 \\
\hline Santia Ersan & 75 & 75 & 75 & 225 & 75 & 75 \\
\hline Valino Aditama M.P & 95 & 100 & 95 & 290 & 97 & 97 \\
\hline Edwar Ridho & 85 & 85 & 85 & 225 & 85 & 85 \\
\hline Wini Oktaviani & 100 & 100 & 95 & 295 & 98 & 98 \\
\hline Saptia Melisa & 100 & 100 & 95 & 295 & 98 & 98 \\
\hline Revan Putra & 75 & 75 & 75 & 225 & 75 & 75 \\
\hline Febri Oktapian & 85 & 85 & 85 & 225 & 85 & 85 \\
\hline Khorida Adilla & 80 & 80 & 85 & 245 & 82 & 82 \\
\hline Aditia Pareza & 95 & 95 & 95 & 285 & 95 & 95 \\
\hline Muharriyatullah & 95 & 95 & 95 & 285 & 95 & 95 \\
\hline Abil Latura & 75 & 75 & 75 & 225 & 75 & 75 \\
\hline Dini Hidayatullah & 75 & 75 & 75 & 225 & 75 & 75 \\
\hline Junasril & 75 & 75 & 75 & 225 & 75 & 75 \\
\hline Jumlah & 1185 & 1190 & 1180 & 3252 & 1185 & 1185 \\
\hline Rata-rata & 84,64 & 85 & 84,28 & 251,7 & 84,64 & 84,64 \\
\hline
\end{tabular}

Dari data di atas menunjukkan adanya peningkatan hasil evaluasi belajar sebesar 5,54\% dari siklus I. Peningkatan nilai menunjukkan bahwa perbaikan proses pembelajaran membawa dampak positif terhadap hasil belajar siswa.

Berdasarkan hasil belajar dan proses belajar yang telah dilaksanakan menunjukkan ada peningkatan baik proses pembelajaran maupun hasil belajar. Hasil belajar sebelum diadakan tindakan kelas mencapai nilai rata-rata $63,4 \%$ setelah siklus I dan siklus II rata-rata nilai $81,4 \%$ berarti ada peningkatan $18 \%$. Hasil prestasi sebelum diadakan, tindakan kelas nilai rata-rata mencapai 79,1\%, setelah siklus I dan siklus II, serta rekomendasi mencapai nilai rata-rata $84,6 \%$ berarti ada peningkatan 5,5\%. Sesuai dengan catatn dilapangan dalam proses pembelajaran rekomendasi dan refleksi berupa perbaikan dan penyempurnaan proses belajar dan mengajar berdampak positif untuk meningkatkan hasil belajar siswa. 


\section{KESIMPULAN DAN SARAN \\ KESIMPULAN}

Berdasarkan penulisan dan pembahasan pada bab sebelumnya maka dapat disimpulkan sebagai berikut :

1. Hasil proses belajar sebelum tumbuh minat membaca mencapai nilai rata-rata $63,4 \%$. Setelah termotivasi minat siklus I dan siklus II, refleksi dan rekomendasi nilai rata-rata mencapai $81,4 \%$, berarti ada peningkatan $18 \%$.

2. Hasil belajar sebelum siklus I dan siklus II mencapai nilai rata-rata $79,1 \%$, setelah siklus I dan siklus II, refleksi dan rekomendasi rata-rata mencapai $84,6 \%$ berarti ada peningkatan 5,5\%.

Maka menumbuhkan minat embaca dapat meningkatkan keterampilan berbahasa Indonesia kelas V SD Negeri 18 Kampung Pansur Kecamatan Koto XI Tarusan Tahun Pelajaran 2014/2015.

\section{SARAN}

Berdasarkan hasil kesimpulan di atas dapat disarankan sebagai berikut :

1. Agar keterempilan berbahasa Indonesia meningkat, siswa harus memiliki minat yang tinggi dalam prosses pembelajaran.

2. Agar hasil belajar siswa bias meningkat secara optimal hendaknya guru menumbuhkan minat siswa dengan perbaikan dan penyempurnaan proses pembelajaran

\section{DAFTAR PUSTAKA}

Adili, Laode. 2008. Pembelajaran Membaca Pemahaman (On line). Artikel, http: //www. SMAN I Ciawi. Sch. id/ listartikel. Php? Id = 41, html. Diakses 24 Maret 2008.

Depdiknas, 2003. Penelitian tindakan kelas. Bahan Ajar Pembekalan Guru Bantu.

Gay, L. R. 1981. Education Research. Meriele Publishing Record Writer.

Kadeci. 2008. Kemampuan Membaca Intensif Siswa Kelas VIII SMP Negeri 27 Makassar. Skripsi. Makassar: UMM.

Mintowati, Maria. 2003. Membaca. Jakarta: Depdiknas.

Muchlisoh, dkk. 1992. Pendidikan Bahasa Indonesia 3. Jakarta: Depdikbud.

Nurhadi, 1987. Membaca Cepat dan Efektif. Bandung : Sinar Baru. 2004. Bagaimana Meningkatkan Kemampuan Membaca? Bandung: Sinar Baru Algensindo.

Moeliono, A.M. 1990. Kamus besar bahasa Indonesia. Jakarta: Balai Pustaka

Nurliah. 2009. Penerapan Metode Pembelajaran Kooperatif Dalam Meningkatkan Kemampuan Membaca Pemahaman Siswa Kelas IV SD Negeri No. 167 Inpres Malewang Kecamatan Polut Kabupaten Takalar. Skripsi. Makassar: UMM.

Oka, I Gusti Ngurah. 1983. Pengantar Membaca dan Pengajarannya. Surabaya: Usaha Nasional.

Soedarsono, F.X. 1987. Pedoman pelestarian penelitian tindakan kelas. Yogyakarta: Dikti.

Susilo. 2007. Panduan Penelitian Tindakan Kelas. Yogyakarta: Pustaka Book Publiser

Sujana, A.S.H. 1988. Modul materi pokok membaca UT. Jakarta: Karunika.

Tampubolon. 1987. Kemampuan Membaca. Teknik. Bandung: Angkasa.

Tarigan, Henry Guntur. 1985. Membaca sebagai Suatu Keterampilan Berbahasa. Bandung: Angkasa.

Tarigan, H. 1987. Pengajaran membaca. Bandung: Ganesa. 